\title{
Ethnic, Immigrant, and Racialized Women in Canada: A Historiography
}

\author{
Julie Dinh
}

Since the emergence of 'new left', bottom up approach to history in the 1960s and 1970s, women's and gender history has become a rich field for historians. Ethnic and immigrant women's history, as part of this larger movement, has seen its own fair share of growth. This paper examines the emergence of racialized women's history in Canada and analyzes the increasingly inclusive and complex integration of this field through the works of notable authors in recent decades.

Parallel to the rising civil and political movements of the 'long sixties' and 1970s, Canadian history saw the emergence of a 'new left' kind of historian. This period was paired by the urgings of several scholars, notably J.M.S. Careless and Ramsay Cook. Historians in these decades began to question and criticize the traditional nationalist and conservative narratives that had been characteristic of how history had previously been written in Canada. The 'new left' began to venture past the 'Whiggish' political and economic narratives of history to study ordinary Canadians. In other words, they began to approach history from the bottom up. Careless' 'limited identities' thesis gained immense traction in this period for a more inclusive re-interpretation of 'big man' history, and social historians turned to class, race, and region as a newly validated focus. While many celebrated this vast change, others criticized the lack of a national history that united Canadians. Although this debate has been a large point of contestation for Canadian historians, the 'limited identity' thesis has nevertheless remained one of the most pervasive and significant ideas in Canadian historiography. Soon, in addition to class, race and region, other areas began to add their sections onto this list, including Aboriginal, African-Canadian, and women's groups to name a few.

Indeed, women's history since the late 1960s has been celebrated as a growing and dynamic area of study. In accordance to the other political rights movements, the increased interest in feminist history coincided with second wave feminism. Generally, feminist history has been significantly affected by the theories and movements of its time. Books like Women at Work: Ontario, 1850-1930 by Janice Acton pioneered women's history, even boldly starting the preface of her book with the statement, "We've only just begun."1 The newly created feminist academic journal, Atlantis, as well as the creation of the Canadian Committee on Women's History (CCWH) also led the way for the expansion of this area.

Amidst the new excitement of reclaiming of women's history, however, there also emerged what Susan Friedman called a tension or anxiety about the "possibility that our feminist reproductions of history may risk repeating patterns of thought that distorted or excluded women from the master narratives to begin with." 2 By the mid-1980s, feminist historians began to be self-critical to and examine the missing stories in their own narratives. Immigration, ethnic and racialized women's history was a significant part of this missing equation. In part because of the larger race-related political issues in Canada (the end of the white-only immigration policy and the Multiculturalism Act of 1985) and the push from women of colour who critiqued feminist history's exclusion of nonwhites, some feminist historians began to ask new questions about race, ethnicity, racism and

\footnotetext{
${ }^{1}$ Janice Acton, Women at Work: Ontario 1850-1930 (Toronto: Canadian Women's Education Press, 1974$), 1$.

2 Susan Stanford Friedman, "Making History: Reflections on Feminism, Narrative, and Desire," in Feminism Beside Itself, ed. Diane Elam and Robyn Wiegman (New York: Routledge, 1995), 14.
} 
marginalization. This paper will examine the historiography in ethnic women's history. My discussion will be of notable works in rough chronological order.

Looking into My Sister's Eyes: An Exploration on Women's History, edited by Jean Burnet, is often touted as being the pioneer for ethnic, immigrant women's studies. Indeed, there had been little published or said about immigrant women and their role in Canada's past before 1985, when the essays that compose this anthology were first presented at the Multicultural History Society of Ontario's conference at the University of Toronto. The essays presented in this compilation are stories of immigrant women, mostly from non-British perspectives in Ontario. Collected and published the following year in 1986, this collection is clear in its goals of introducing ethnic and immigrant women as valid and significant actors in Canada's past, as well as motioning forth new opportunities for discussion. In Burnet's own words, these essays simply "give a new and richer nap to the fabric."3

The authors in this text deserve recognition for moving past the old 'add women and stir' concept associated with many feminist historians. Instead, critics commend these essays for their recognition of ethnic women, as individuals and as groups, who were often marginalized even within women's history. Furthermore, these groups were shown to be active participants and actors in their own lives and in their spheres.

The compilation boasts a diverse range of topics, featuring varied chronologies, ethnicities, and emphases of the women's groups. The ethnicities 'uncovered' are varied, with British, Italian, Finnish, Jewish, Polish, Greek, Macedonian, Armenian, Ukrainian, Chinese, and Mennonite women represented by each of the authors. Furthermore, the authors emphasized different aspects of the women's lives, from charity, church organization, the family, to domestic work. Franc Sturino, for instance, discusses how women's roles "as potential wives, as wives and as mothers" affected their emigration experience and the particular expectations placed on them. ${ }^{4}$

By contrast, authors like Varpu Lindstrom-Best and Marilyn Barber focus on the working lives of Finnish and British women respectively. An emphasis on class consciousness is much more evident in these works. Readers are offered a new, richly multidimensional perspective on these groups of immigrant women. At the very least the authors fulfill their goal of "trying to develop new perspectives and to pay attention to people and to areas of life previously ignored." However, these topics are noticeably still within stereotypical women's spheres.

Despite the heterogeneous topics and content of the essays, there are some common themes that stand out in this book. Among them are women's individual roles in the family, in ethnic community-building (through different frameworks such as the church and charity), and the economic and social marginalization experienced by most immigrant groups. In a sense, there is a portrayal of unity that forms between the numerous ethnic groups. An interesting contradiction is therefore present in this book because despite the different contexts, decades, and cultures, the collection still suggests that the different ethnic groups share a general common thread.

However, one must wonder whether these commonalities are too forced. Are gender and a broad description of 'marginalized' enough of a unifying factor? The main concern with Looking into My

\footnotetext{
3 Jean Burnet, "Introduction" in Looking Into My Sister's Eyes: an Exploration in Women's History (Toronto: Multicultural History Society of Ontario, 1986), 2.

4 Franc Sturino, "The Role of Women in Italian Immigration to the New World" in Looking into My Sister's Eyes (Toronto: Multicultural History Society of Ontario, 1986), 25.

${ }^{5}$ Burnet, Looking into My Sister's Eyes, 5.
} 
Sister's Eyes is that it lacks a deeper analysis on the conflicts that did exist for these women-often in ways that would undermine this image of unity. Although the authors do to some extent acknowledge class, generational, and race tensions, these conflicts are mostly either downplayed or swept aside. For example, in Lindstrom-Best's essay on Finnish domestics, she curiously states that the Finnish domestics "decided to investigate the possibility of joining the existing Domestic Servant's Union, mainly made of Chinese domestics. Nothing came of this joint venture."6 Undoubtedly, this is an interesting observation. However, Lindstrom-Best does not elaborate on this point. Was the major presence of Chinese domestics a factor in this? It would appear so, judging from Lindstrom-Best's mentioning of them-however, no further attention is given to the relationship between ethnic groups. While I acknowledge that these authors were aware of the racism experienced by these groups, there seems to lack a deeper analysis of the extent of marginalization and its sources.

Furthermore, Looking into My Sister's Eyes lacks sufficient representation of visible minorities. Other than Dora Nipp's "'But Women Did Come': Working Chinese Women in the Interwar Years,"7 other visible minority groups were left out. Despite these concerns, Looking Into My Sister's Eyes still deserves credit for being one of the first to start this discussion. Although it can be criticized for its rather straightforward retelling of racialized women's history, at the very least, this book challenges the notion that all women had the same experiences or were merely passive participants in Canada's immigration history.

As the volume of feminist historians' work grew in the 1980s and 1990s, so too did the work on differences and conflicts within women's history that was so lacking in Burnet's collection. This notable shift in perspective seems to align with the rise of the 'posts' in the 1990s and beyond-by this I mean post-structuralism, post-modernism and post-colonialism. Some scholars, notably Mariana Valverde and Franca Iacovetta in their compilation, Gender Conflicts: New Essays in Women's History, published in 1992, called for a partial rejection of the social history that emerged in previous decades which they saw as celebratory and that had "neglected the class bias and xenophobic views and practices of some of the women studied." 8 By contrast, the editors called for a more 'complex' form of history that emphasized the processes and relational developments of gender, rather than just a focus on women's studies.

However, there are some who have been highly critical of this new 'gender' history approach. Joan Sangster is vocal in her disagreement with this new direction. In her article, "Beyond Dichotomies: Re-assessing Gender History and Women's History in Canada," she describes the trend as a new interpretation that "situates women's history in the one dimensional past, gender history in the three dimensional future." According to Sangster, gender history is deemed superior by new feminist historians because it addresses the complexities that new left historians either missed or ignored in their uncovering of women's history. Sangster argues that this sense of 'progress' held in gender history is Whiggish and creates a dichotomous way of reflecting on history. In addition, she argues that a relational understanding of gender and the attention given to masculinity will surely

\footnotetext{
${ }^{6}$ Varpu Lindstrom-Best, "I Won't be a Slave! Finnish Domestics in Canada, 1911-1930” in Looking into My Sister's Eyes (Toronto: Multicultural History Society of Ontario, 1986), 48.

${ }^{7}$ Dora Nipp, "But Women Did Come: Working Chinese Women in the Interwar Years" in Looking into My Sister's Eyes (Toronto: Multicultural History Society of Ontario, 1986).

${ }^{8}$ Mariana Valverde and Franca Iacovetta, "Introduction," Gender Conflicts (Toronto: University of Toronto Press, 1992), xv.

${ }^{9}$ Joan Sangster, “Beyond Dichotomies: Reassessing Gender and Women’s History,” Labour History 3, no.1 (1995): 109.
} 
undermine women's history. Furthermore, Sangster criticizes post structuralism for 'hedging' Canadian history, thus undermining real sources of oppression.

Lynne Marks and Karen Dubinsky offer an equally interesting defense of gender history in their article, "Beyond Purity: A Response to Sangster." They criticize Sangster for the "narrowness of her vision" in her categorizations of Canadian feminist history throughout the decades, while also adding that these categories of 'good feminist' and 'bad feminist' are of her own creation. ${ }^{10}$ Furthermore, they refute Sangster's position by arguing that the attention given to masculinity (or masculinities) will only bolster feminism by further analyzing the maintenance of power relations and deepening the understanding of how people 'do' gender. Most significantly however, these authors rightly argue that "Far from drowning under the dead weight of post-structuralism and gender analysis, as Sangster implies, we think that these days feminists are carving out fascinating new topics and re-invigorating old ones." "11 Sarah Carter and Franca Iacovetta's works, analyzed more in detail later in this paper, are good examples of the re-invigoration of old topics by new ideas.

Burnet's own recognition that "much remains to be done"12 was the inspiration behind a newer anthology published in 2004 called Sisters or Strangers? Immigrant, Ethnic, and Racialized Women in Canadian History. Appropriately, the editors, Marlene Epp, Frances Swyripa, and Franca Iacovetta were contributors to Burnet's collection eighteen years earlier. There is a notable re-analysis of women's relationships in this newer anthology. While Burnet's work presented much more uncomplicated tales of immigrant women's experiences in Canada via community building and ethnic unity, the editors in this anthology emphasize what Burnet minimizes: conflicts and problems in a so-called 'sisterhood'.

Sisters or Strangers, although published much later than Gender Conflicts, reflects many of the same post-structuralist and post-modernist ideas and can be situated in this debate. In keeping with the times, the editors were much more hesitant and critical of the unity and relative simplicity which had been portrayed in the earlier collection. Instead, the authors attempt to advance this discussion by complicating previously accepted dichotomies of the woman/man, white/non-white binaries. They emphasize the complexities of immigrant women's lives, making them 'sisters' in some context dependent cases and 'strangers' in others. In effect, there is an analysis of the multifaceted connections between race, gender, class, age, and religion and how these factors have an impact on the sometimes problematic interactions between women and their families, where "immigrant families were not just cohesive bulwarks against Canadian society but also sites for marital discord and generational conflict," communities and the state. ${ }^{13}$ Indeed, the compilation is very ambitious in its aims. Although there is no clear consensus in any of the essays presented, the theme that is reiterated over and over again is complexity.

Notably, this collection boasts a massive range in its chronologies, number of ethnicities and topics. Like Looking into My Sister's Eyes, this collection attempts to cover a multitude of ethnicities and, to its credit, also addresses more visible minorities. This book also expands its territorial boundaries past Ontario to a national level. However, it does not provide any information about the Maritimes and the Canadian north. Spanning 200 years of Canadian history, the book addresses numerous

\footnotetext{
${ }^{10}$ Lynne Marks and Karen Dubinsky, “Beyond Purity: A Response to Sangster.” Left History 4, no. 1 (1996): 205.

11 Ibid., 206.

12 Burnet, Looking into My Sister's Eyes, 6.

${ }^{13}$ Marlene Epp, Francis Swyripa, Franca Iacovetta, "Introduction" Sisters or Strangers? Immigrant, Ethnic, and Racialized Women in Canadian History (Toronto: University of Toronto Press, 2004), 11.
} 
aspects of immigrants' lives, from media representation of Finnish women during the Winter War to the gender politics of food and assimilation. The enormous scope of this book is thus made coherent by a variety of themes separated into six parts: Race and Nation-Building, women's encounters with the state (both in the courts as domestic violence victims and through political movements), women's relationships within their own community and self, symbolism and representations of women and finally, the history and memory of women's experiences.

Similar to Looking into My Sister's Eyes, most of the authors identify with the ethnic group that they discuss, making the essays fairly reflective. Although one could argue that this might lead to a bias in their work, I believe that this is a strong aspect for this book overall because the authors use their own memories to add description and paint illustrative life into their work. For example, Midge Ayukawa offers the reader a thoughtful reflection on her own childhood memories of her mother and childhood bullies in her essay, "Japanese Pioneer Women: Fighting Racism and Rearing the Next Generation." ${ }^{14}$ Likewise, Kaprelian-Churchill's essay on Armenian intermarriage, "Odars and 'Others': Intermarriage and the Retention of Armenian Ethnic Identity"15 is influenced by her own marriage outside of the Armenian community and her reflections on retaining her Armenian culture despite marriage to a non-Armenian.

There are also disagreements between several authors. For example, Mar's depiction of Asian immigrant families is characterized very differently than Ayukawa's. On one hand, this could be seen as a weakness for this collection. However, because the authors do not hesitate to address each other in their work, and because the emphasis for the collection is discussion, discourse, and complexity, these disagreements provide a multidimensional analysis of ethnic groups and allow room for further expansion.

As with all anthologies, some of the essays are stronger or more innovative than others. For example, Mar's essay on Lin Tee seems a little awkward in its analysis of Lin Tee's mental capability and how it reflected racial/gender biases. On the other hand, some of the strongest essays in this collection were the exploration of 'whiteness' and masculinity, two areas that were lacking in Burnet's collection. 'Whiteness' and its role in nation-building is particularly expressed in Adele Perry's, "Whose Sisters and What Eyes? White Women, Race, and Immigration to British Columbia, 1849-1871." Perry offers a valuable study on 'whiteness' and its ascribed idyllic virtues of white females in nation building in British Columbia. She shows that white women were both the 'colonized' and 'colonizer', while also simultaneously "confirm[ing] and challeng[ing] the racial mission." In this sense then, the reader can grasp a sense of the multiplicity of identity, expectation, and reality.

In addition, the authors support the idea that gender is relational by addressing men's experiences and studying how masculinity and femininity were both created and maintained in these groups, as well as how it was imposed by larger society. The two notable examples of this analysis are from Barrington Walker and Lisa Mar, authors of "Killing the Black Female Body: Black Womanhood, Black Patriarchy, and Spousal Murder in Two Ontario Criminal Trials, 1892-1894" and "The Tale of Lin Tee: Madness, Family Violence, and Lindsay's Anti-Chinese Riot of 1919” respectively. Both

\footnotetext{
${ }^{14}$ Midge Ayukawa, "Japanese Pioneer Women: Fighting Racism and Rearing the Next Generation" in Sisters or Strangers? (Toronto: University of Toronto Press, 2004).

${ }^{15}$ Kaprelian-Churchill, "Odars and Others: Intermarriage and the Retention of Armenian Ethnic Identity" in Sisters or Strangers? (Toronto: University of Toronto Press, 2004).

16 Adele Perry, "Whose Sisters and What Eyes? White Women, Race, and Immigration to British Columbia, 1849-1871" in Sisters or Strangers? (Toronto: University of Toronto Press, 2004), 52.
} 
essays show how the ethnic man's body was as much racialized and gendered as a woman. For example, black men were seen as domineering and inherently violent while Asian men's temper and abuse inspired a riot in Lindsay.

In sum, Sisters or Strangers is a good introduction to the new discourses of gender history. By refuting the existence of set dichotomies and emphasizing complexity and the relational nature of gender, the editors are successful in introducing broad themes to their readers.

Even with the existence of the internal debate of feminist historians (as shown through the article by Joan Sangster and the responses of the 'new' new left), there still remains the wider contentious debate between nationalist, materialist history and social history. Jack Granatstein's and Michael Bliss' often quoted works are indicative of the hostility and still-present fear that social history, and its pre-occupation with race, class, and gender undermines the national Canadian story, thereby weakening Canadian identity and the teaching of it. Many social historians (including the ones reviewed in this essay) defended their studies with slogans like 'Women's history is Canadian History', while others cited the existence of a vertical mosaic as validation for their study. Much ink has been spilt over this debate.

However, in some more recent works, notably by Franca Iacovetta and Sarah Carter, there seems to be less of an ideological war between national history and social history. In their own ways, both walk the line between the two, presenting a history of marginalized groups but show that their conclusions are equally revealing of the nation building processes. This is reminiscent of the arguments for the importance of social history by the editors of Sisters or Strangers who stated that "the evolution of a national story - if such indeed exists - revolves much around the interaction between and negotiation over privilege and power among people with various backgrounds, histories, and experiences based on group identifications." 17

In 2006, Franca Iacovetta's book, Gatekeepers: Reshaping Immigrant Lives in Cold War Canada, further contributed to the this topic. Iacovetta, who was also an editor of Sisters or Strangers? has published extensively on the study of ethnic, immigrant, and racialized women's history; she was also an editor of the previously mentioned book, Gender Conflicts. Although she mostly focuses on Italian immigration in her previous work, Gatekeepers is the study on a broader group of Cold War immigrants and their relationship to Canadian 'gatekeepers', who include but are not limited to the press, social workers, teachers, and community organizers of Canada. While she uses much of the discourse of post structuralist gender history, including an understanding of gender as a social relation, Iacovetta situates these phenomena within the context of the Cold War. Furthermore, many of the arguments and analyses made in this book are equally revealing of Canadian society and psyche during this period, therefore making this book a good combination of nationalist and social history.

Canada changed drastically demographically after the Second World War, as a large stream of immigrants from Europe entered the country. Between 1946 and 1962, more than 2.1 million Ukrainians, Poles, British, Jews, Russians, and Germans, to name but a few, immigrated from war torn Europe. ${ }^{18}$ Iacovetta's argument is based on the idea that the context of the Cold War shaped the perception, and thusly the experience of immigrants at this time. Although the paranoia and fear in the United States is widely known, Canada was not immune to Cold War paranoia either. In her own words, she explains that the

\footnotetext{
${ }^{17}$ Epp, Swyripa, Iacovetta, Looking into My Sister's Eyes, 8.

${ }^{18}$ Franca Iacovetta, Gatekeepers: Reshaping Immigrant Lives in Cold War Canada (Toronto: Between the Lines, 2006$), 10$.
} 
Cold War served to introduce the prevailing gender ideologies and conventional moral and sexual norms of the era and to impart an even greater sense of urgency to reception and citizenship activities... by which mainstream North America sought to bolster and impose 'the archetypal white, middle-class family of the $1950 \mathrm{~s}^{\prime} . .{ }^{19}$

In other words, morality and success were equated with democracy and by contrast, immorality, sexual deviance, poverty and ugliness with the dreaded Communism. In effect, the gatekeepers that interacted with the newcomers attempted to mould these groups into their ideal versions of democratic citizens by simultaneously 'uplifting' immigrants to the abundance and standard of living promised in democratic, capitalist Canada, and also by 'containing' the Communist immorality of the people, namely through norms of sexual deviance and child rearing. Thus, the sources of marginalization and oppression are shown to be further than the race, class, and gender triumvirate but also include state and economic ideology. Her use of Communism, capitalism, and democracy to explain the motivations and psyche of both the immigrants and the Canadians is innovative and interesting.

Generally, Iacovetta is successful in painting a vivid picture of the immigrating ethnic groups. While being careful not to homogenize the immigrants into one ethnic clump, she offers the reader an interesting, thoughtful, and detailed explanation of the background of these people, through both wider stories and individual personal narratives. In addition, she often refers to the conditions and lives of newcomers pre-immigration throughout her work. This is important because a fuller understanding of the immigrants' experiences is only possible by having the context of their lives, something missing in some of the essays in Looking into My Sister's Eyes and Sisters or Strangers?. In other words, this attention to their unique background allows Iacovetta to see them as vibrant groups instead of homogenized ones.

Her analysis really begins after the first chapter, where she divides the remainder into sections or areas the gatekeepers tried to 'uplift' and simultaneously 'contain' in the immigrant population, namely through the press, ethnic organization, the family, food, and sexuality. Some of the themes that are reiterated throughout these chapters are the ideals of Capitalism, negotiation, the paradox of 'unity in diversity' and assimilation pressures, intergenerational conflict and the anxiety about sexual and moral deviance. Each social aspect that the Gatekeepers influenced or at least attempted to is thoughtfully written using a variety of sources and an ample amount of useful photographs.

Especially eye-opening is Iacovetta's discussion of the less obvious methods of integrating immigrants, particularly through food ways. Iacovetta's chapter on food is an innovative way to incorporate the themes of assimilation, Canadianization, culture retention and the promotion of 'kitchen consumerism.' Iacovetta argues that food culture "was no less political than were the workings of the ethnic organizations and press" and convincingly makes a case for this. ${ }^{20}$ Used as a tool for assimilation, certain food habits (including the encouragement of 'Canadian' food), and kitchen consumerism symbolized the capitalist ideal of health and prosperity. Newcomers were thusly often judged on how 'Canadian' their diets were, resulting in ethnic hierarchies that generally reinforced pre-existing stereotypes, such as the German's and Swede's adaptability and the Italian population's primitiveness.

Iacovetta also incorporates a gender analysis on food culture, as she does with all of her themes arguing that the signs of changing status for women in society led to an anxiety about the breaking

\footnotetext{
${ }^{19}$ Iacovetta, Gatekeepers, 19.

20 Ibid., 137.
} 
down of gender roles. In other words, the worry that women were gaining too much freedom and autonomy led to a backlash and reinforcement of the homemaker ideal, where women's focus was on 'women's primary responsibility for feeding and nurturing healthy families, managing modern, efficient, and well-equipped households, and raising well-adjusted children."21

However, food culture was also the setting for a more complex interaction of ethnic hierarchy, negotiation, intergenerational tension, and class. It was a way in which an observer could see the interactions and negotiations between immigrants and Canadians, where some cultural retention and tradition was celebrated or disputed. Classes and special movies reinforced the role of women in this process, often emphasizing women's responsibility in conforming to the homemaker ideal. The less they conformed, the more un-Canadian they seemed, negatively impacting their citizenship. Her analyses of the ethnic community parties are especially useful, as she connects how the 'dumbed down' version of foreign foods (such as pizza made with crackers and cheddar) was a way for society to make the ethnic groups seem less threatening. Therefore, the effects of interaction and assimilation were two sided-Canadian society adapted to these immigrants as well.

Consistent with previous works, the idea that gender is relational is prevalent in this book. Although gender and gender ideology is a constant theme in Gatekeepers, Iacovetta does not write this about women's history exclusively. Her focus on masculinity is especially apparent in the gender roles that were imposed on both men and women in regards to family. The decades after the Second World War were marked by a growing fear of the uprooting of gender roles, where "unemployed fathers had lost their self-respect and were reduced to weeping emotional wrecks — a crisis in masculinity."22 Masculinity was thus expressed through the traditional bread-winning role. Again, this ties in with ideas of the ideal capitalist family. However, she does make the case that "while in the packaged portrait of pleasant ethnic folk applied to both men and women, it was in some significant respects most commonly gendered female." 23

One of the most creative and intriguing parts in this book is Iacovetta's use of psychology in her analysis. The mental health of the immigrants was one of the key issues for Canadian psychologists and social workers. This is significant because she clearly demonstrates how the values of the Canadian gatekeepers were so ingrained into their psyche that nonconformity to democratic or capitalist venture was considered part of a mental deficiency.

However, too much of the analysis and examples of this book are focused on one region: Ontario. Iacovetta does not address regional disparity. Therefore it is unlikely that her conclusions can be applicable nation-wide, especially since many historians have argued that regional identities are strong components in Canadians' lives.

Despite the small number of shortfalls, Iacovetta's book is a well written, creative, in depth analysis on the Canadian psyche in the Cold War and how it translated over into specific beliefs about assimilation, gender, sexuality, family and morality. Iacovetta is clearly critical of these gatekeepers.

The social expectations forced onto ethnic groups are echoed, albeit in a different context, in Sarah Carter's work. Carter's contribution to this realm of social history is perhaps one of the more creative of the ones discussed here. Carter's focus on Aboriginal women is part of the larger discussion that emerged in the 1990s and the popularization of postcolonial theory. The shift of feminist history to the 'internal' colonies and Canada's imperialist past led to the rediscovery for

\footnotetext{
${ }^{21}$ Ibid., 139.

22 Ibid., 175.

${ }^{23}$ Ibid., 98.
} 
many to look at the marginalization of Aboriginal groups. Aboriginal women, consequently, were a topic of interest to feminist historians who could draw parallels between other ethnic group's experiences as outsiders even within women's history. Published in 2008, The Importance of Being Monogamous is an analysis on the ideal of monogamous marriage and its enforcement by Canadian officials to the Canadian west, particularly to Aboriginals. It is a telling history of the importance of gender and moral expectations and how these can be ascribed by the state.

Reminiscent of Iacovetta's arguments that certain social aspects, such as food and sports, were a symbol of democracy, Carter's stress on the importance of marriage contains quite similar ideas. Marriage, she argues, "served as a metaphor for voluntary allegiance and permanent union, the foundation for national morality." 24 Attached to this importance were also monogamy, sexual and moral discipline and an imperialist belief that women benefitted from this union. Strict ideas about gender, sexuality, and monogamy then, were not just a symbol of how Canadians were civil, but also the justification that 'others' were not.

Carter also spends much time arguing that Aboriginal 'marriage' was, in fact, legitimately constituted marriage. Her stance puts her at odds with other scholars because she argues that the definition of marriage has changed over time, making the notion of marriage interpretative. Her definition of marriage is purposefully vague and reminiscent of post-modernist ideas about language.

Unlike Iacovetta, Carter focuses on the Canadian West. She argues that Western Canada "presented particular challenges to the national agenda in the late nineteenth century, as the region was home to a diverse population with multiple definitions of marriage, divorce, and sexuality." 25 Included in this were Aboriginal, Mormon, Ukrainian, Chinese, and Black ethnic groups. Therefore her argument that marriage ideals were even more important in the expanding Canadian West is warranted. Because of the relatively significant presence of these other ethnic groups that did not conform to gender or sexual ideals, marriage became an even more important process for imposing these values. In fact, she states that "white female domesticity would be the pervasive theme of the new era dawning in the history of the west." 26

In addition, Carter's discussion of the interactions between the ethnic groups and the state is revealing and detailed. Many chapters of the book are dedicated to describing the numerous ways in which officials attempted to impose the monogamous marriage principle. The book explores strategies such as altering and limiting Aboriginal marriage laws, to the role of residential schools on the forming of unions. Similarly, the resistance that this effort was met with was also formidably discussed. Overall, Carter analyses the process of oppression and the interactions that forced these values very clearly and concisely.

One of the biggest strengths in Carter's book is the potential for cross-cultural comparative work, both historically and presently. By arguing that the definition of marriage has not historically always been between one man and one woman, Carter's book is useful in challenging the misconceptions of present day marriage. In a broad sense, it forces the reader to re-think the concept of marriage as it has been generally presented. She shows that marriage is much more fluid and is really only a product of modern day.

\footnotetext{
${ }^{24}$ Sarah Carter, The Importance of Being Monogamous: Marriage and Nation Building in Western Canada to 1915 (Edmonton: University of Alberta Press, 2008), 4.

${ }^{25}$ Ibid., 5 .

26 Ibid., 21.
} 
However, a more in-depth analysis of the other internal dissenters is needed to further strengthen this book. Although the focus of her work was on Aboriginal and, to a certain extent, Mormon populations, she does mention Ukrainian, Chinese and Black populations. A further discussion on how well these groups fit into her larger work would have been a useful comparison.

Like Iacovetta's Gatekeepers, Carter manages to walk a fine line between materialism and social historical analysis. By analyzing nation building in a new way and incorporating gender, race, and sexuality into the mix, the Canadian West is shown to be, in large part, a product of the ascribed and forced values of an oppressive, morally panicked government. Her bold statement at the beginning of the book that "To be interested in Canadian identity is to be interested in marriage" 27 is justified because of this strong association of marriage, morality, power, and nationhood.

For feminist historians, there will probably be a continuation of this growing scholarly expansion and interest for years to come. Because ethnic female and gender history are relatively new, growth will surely continue. Ethnic women's historiography, in many cases, is not about the simple re-telling of popular events by adding them into consideration. The books discussed in this essay have explored the experiences, differences, commonalities, and relationships of immigrant, ethnic, and racialized women. Ordered chronologically by the year of publication, these works are connected in very loose thematic ways - otherwise, the populations of women, timeframes and subjects that the authors study are quite different. Instead, these authors have started by asking: Who are these immigrant women and what were their experiences? As the stories of passage, settlement, community and nation building, and survival begin to appear in the 1970s and 1980s, the questions become more complex and historians began to be more critical of who was represented in history and who was being left out. As the 'post' theories began to gain prominence in feminist history, some feminist historians criticized this new perspective for undermining women's history and hedging the more classic sources of oppression that have traditionally been cited.

Furthermore, feminist history has been part of a larger debate of whether history of this kind is essentially undermining Canada's unifying national history. While this debate will not likely be solved in the near future, perhaps social historians and conservative nationalists will find a way to balance their work. Sarah Carter and Franca Iacovetta have both produced works that would probably satisfy both camps. However, while Iacovetta and Carter have undoubtedly given readers a thoughtful perspective on nation building, both authors' work, in particular Carter's, still leans more towards social history. Perhaps then a perfect reconciliation is neither possible nor fruitful. Either way, gender history will keep moving in this direction of re-analyzing many shared Canadian histories and uncovering new perceptions and sources of oppression.

${ }^{27}$ Ibid., 4 . 


\section{Bibliography}

Acton, Janice. Women at Work: Ontario 1850-1930.Toronto: Canadian Women's Education Press, 1974.

Burnet, Jean, ed. Looking into My Sister's Eyes: an Exploration in Women's History. Toronto: Multicultural History Society of Ontario, 1986.

Carter, Sarah. The Importance of Being Monogamous: Marriage and Nation-Building in Western Canadato 1915. Edmonton: University of Alberta Press, 2008.

Dubinsky, Karen., Marks, Lynne. “Beyond Purity: A Response to Sangster.” Left History 4, no. 1 (1996): 967.

Epp, Marlene., Iacovetta, Franca., Swyripa, Frances, eds. Sisters or Strangers? Immigrant, Ethnic, and Racialized Women in Canadian History. Toronto: University of Toronto Press, 2004.

Friedman, Susan. "Making History: Reflections on Feminism, Narrative, and Desire" In Feminism Beside Itself, edited by Diane Elam and Robyn Wiegman, 14. New York: Routledge, 1995.

Iacovetta, Franca. Gatekeepers: Reshaping Immigrant Lives in Cold War Canada. Toronto: Between the Lines, 2006.

Iacovetta, Franca., Valverde, Mariana, eds. Gender Conflicts: New Essays in Women's History. Toronto: University of Toronto Press, 1992.

Sangster, Joan. "Beyond Dichotomies: Reassessing Gender History and Women's History in Canada." Left History 3, no. 1 (1995). 